\title{
Neoliberal Issues in Public Education
}

\author{
Carol A. Mullen • Fenwick W. English • \\ Sue Brindley $\cdot$ Lisa Ehrich $\cdot$ Eugenie A. Samier
}

We finished penning this special issue and sending it to press on Martin Luther King Jr. Day. We take pause, honoring Martin Luther King's memory and we are dedicating this project to his profound vision as a public intellectual and world activist for whom two of his breakthrough ideas are particularly relevant to this collection. The guest editors, along with the contributors, are reinforcing his messages for the current and future eras that "leadership is the action of ideas to make change, through the agency of individuals" (p. 74) and that "Injustice anywhere is a threat to justice everywhere" (p. 75) (see Temes 1996).

This year, Inauguration Day, coincides with Martin Luther King Day for only the second time in history. The only other time the two holidays have fallen on the same day was during the 1997 inauguration of President Bill Clinton. This year also commemorates the 150th anniversary of the Emancipation Proclamation signed by

C. A. Mullen $(\bowtie)$

Virginia Tech, 226 War Memorial Hall (0313), Blacksburg, VA 24061, USA

e-mail: camullen@uncg.edu

F. W. English

3001 Staffield Lane, Chapel Hill, NC 27516, USA

e-mail: fenglish@attglobal.net

S. Brindley

Faculty of Education, University of Cambridge, 184 Hills Road, Cambridge CB2 8PQ, UK e-mail: sb295@cam.ac.uk

\section{Ehrich}

School of Learning \& Professional Studies 1, Faculty of Education,

A Block Queensland University of Technology 1, Kelvin Grove Campus,

Victoria Park Road, Kelvin Grove, QLD 4059, Australia

e-mail: 1.ehrich@qut.edu.au

\section{E. A. Samier}

Faculty of Education, The British University in Dubai, Dubai International Academic City (DIAC), 1st \& 2nd Floor, Block 11, PO Box 345015, Dubai, United Arab Emirates 
Abraham Lincoln on January 1, 1863. Fittingly, when President Barack Obama takes the oath of office his hand will be on two Bibles: one belonging to President Abraham Lincoln and the other belonging to Reverend Martin Luther King.

We are excited to be introducing the first of two consecutive issues within a volume concerned about neoliberal issues in public education. The genesis of the idea for this special issue arose out of conversations that Carol Mullen and Fenwick English had subsequent to a book we had just finished with colleagues titled Educational Leadership at 2050 (English et al. 2012). That work we have nicknamed 2050 challenges the legitimacy of dominant knowledges and power structures, and is essentially a critique of neoliberalism as it has been unleashed on the world today. Our goal was to question assumptions - about learning, schooling, and leadership — and to remind educators, worldwide, to foster authentic schooling as systems around the world hurtle toward standardization and hyper-organization.

We decided to further explore the topic of neoliberalism but with an international group of scholar-practitioners. Our goal was to learn about others' understandings of neoliberalism, both in theoretical terms and as practice, and people's views of such changing worldwide phenomena as global capitalism, the economic ideological stances of free-market competition, and the privatization of state social services. In other words, we (Fenwick and Carol) recognized with greater clarity after writing 2050 that, along with other scholars, we held strong critical opinions about the rise, within the last decade, of neoliberal foundations and think tanks that privatize and commodify public spaces and with it educational preparation. As many scholars attest, neoliberalism is a political force working to reshape relationships and ideas regarding changes within the field.

For this special issue project, we reached out to prominent scholars from outside the United States to help broaden and deepen this conversation and to give it a global interface. In this endeavor, we were joined by educational leadership and teacher education professors Sue Brindley of the United Kingdom, Lisa Ehrich of Australia, and Eugenie Samier of the United Arab Emirates.

Banded together as a group of five guest editors, we sought out the ideas of scholars from around the world about the global thrust towards market driven economies and neoliberal political agendas. Neoliberal foundations and think tanks such as Heritage Foundation, the American Enterprise Institute, and the Broad and Gates Foundation deny the efficacy of the structures of the educational leadership and teacher education fields, for example-some neoliberal policymakers and others posit that licensure and professional preparation standards and programs are unnecessary. This stance amounts to a denial of the entire field of educational leadership preparation, for example, and a negation of its legitimacy (English 2011). We believe that neoliberal foundations and think tanks have worked to deprofessionalize leadership and teacher preparation for political gain.

Neoliberal politicians, mostly but not exclusively Republicans, backed by lavishly funded right wing think tanks and neoliberal philanthrocapitalists have succeeded in giving teacher unions and school boards "black eyes" in the larger body politic. Teacher unions have become the favorite punching bag for standing as "obstacles" to what the neoliberals label "reforms" but which are really their 
political ideologies and agendas for exerting corporate style management and marketization being implemented in $\mathrm{K}-12$ public schools.

Schools of education have come under fire by neoliberal politicians from both sides of the aisles, funded and pushed by right wing think tank pundits and venture philanthrocapitalists such as Eli Broad and neoliberal payroll pundits such as the American Enterprise Institute for Public Policy Research's (AEI) Frederick Hess and the Fordham Institute's Chester Finn. However, the idea that licensing or experience in education is unnecessary is a familiar one to the neoliberal agenda and is not confined to education. For example, it is now being argued that the practice of law should be "de-regulated" and that the control of entry to the law profession via law schools and the American Bar Association should be changed because it would make legal services cheaper and create more jobs. As in the attack on leadership preparation in schools of education, it is argued that competition for law services would lead to more efficient methods for serving clients.

French sociologist Pierre Bourdieu produced a powerful critique of free-market politics, a source that is drawn upon many times in this special issue. He wrote about the withdrawal of the state from crucial areas of social life and attacked the dismantling of public welfare in the name of private enterprise and global competitiveness. Bourdieu stood up for the interests of individuals, groups, and social movements whose views are ignored in the current climate of market triumphalism. His vision of internationalism defends the collective and individual social rights of ordinary people against the prerogatives of the marketplace. Bourdieu (1998) has critiqued "the air of a message of liberation" that neoliberalism generates (p. 50), a point of view that we share. For example, we, the guest editors and contributors alike, believe that neoliberals try to pass off their ideology as "common sense" without acknowledging that it is simply their point of view and they rarely acknowledge their hidden agenda of imposing the "for profit" mindset on public services.

Take, for example, the culture of corruption across the full spectrum of the "forprofit" online degree mills. These put the lie to the neoliberal claim that competition improves quality or reduces cost. And the public is not convinced of the efficacy of online programs, as national surveys have shown. We believe that the time is ripe for a re-centering of our field, towards orienting leadership practice and teacher preparation around issues of pedagogy as opposed to those of management. The isolation of such programs has accentuated the "generic managerialism" of the neoliberal assault on our programs. The albatross of the argument goes something like this: Business management techniques are superior to those found in schools of education, and that it makes no difference where leaders (and teachers!) are prepared-we simply need to find those most genetically disposed towards "greatness."

The pushback on corporate managerialism must begin with re-centering educational leadership and teacher preparation around matters of teaching and learning. With neoliberal agendas controlling work in many countries and shaping the future of education, the guest editors have asked, how do neoliberal groups and interest think tanks network? What is this agenda and how does it influence not-forprofit and for-profit universities, and public institutions and private sectors? 
"Neoliberal Issues in Public Education" is a timely and significant theme for fostering critical thinking, inquiry, and activism about neoliberal agendas, influences, and networks. Viewed in very different ways, some people see neoliberal agendas as protecting or even elevating human freedom through privatization. The motivation is to concentrate power and wealth in the hands of a few-such as transnational corporations and global elite groups. Others see these undermining transparency and accountability, proliferating anti-democratic thinking, and, more extreme, promoting attacks on disenfranchised groups and on public education.

While networking has become popular, worldwide, serious study is needed of its ideological scope and consequences as exclusionary systems that through globalization reduce all sectors to an economic model and values. Currently, the attention from researchers is on organizational effectiveness and school improvement. A neoliberal strategy includes generating networks of lavishly funded foundations, adding to the regulatory weight of marketeers that dispels critical inquiry, abandons social justice agendas, and worsens economic and societal disparities. It is time to reclaim public education, internationally, by generating knowledge about this sociopolitical agenda.

The 16 authors from issues one and two have written papers that describe as well as problematize neoliberal issues, influences, and networks. Focused but varied inquiry on pivotal issues in education are explored through rigorous approaches to empirical research and in-depth, "edgy" argumentation. The topics covered in the special issue across the two-part volume include the following and expand beyond this list:

- Intersections between democratic and neoliberal agendas, tensions between restricted-access networks and open-access networks, and communities of practice and regulatory bodies

- Analysis of the work between school districts and preparation programs as related to neoliberal agendas

- Networked learning within national and international consortia of teacher and leadership preparation programs

- Probing of networks within "policed" states and trends relating to privatization and the depoliticization of education

- Discussion of hidden but emerging systems that influence the neoliberal agenda in a region or the world

- Need for open and critical dialogue relative to neoliberal agendas (e.g., corporate marketing schemes)

In the four featured articles that follow, the authors who are currently working in universities in the US, the UK, and the UAE describe neoliberalism in ways that are engaging, provocative, and even somewhat arresting. Key concepts used collectively by the group is revealing of the associations we have with neoliberalism, as well as our critiques and alternatives (e.g., faculty voice and democratic decision making). Grouped together without positive or negative values of neoliberalism labelled in this broad swipe, major concepts the contributors describe are neoliberalism (e.g., neoliberal networks, agenda, culture, politics), globalization, Regressionsverbot, epistemic frame, leadership listening, faculty voice, democratic decision making, college faculty governance, corporatization of the university, 
popular culture, social capital, social reproduction, social Darwinism, education austerity, democratic public school, and unitary school system. In the second issue that follows this one, the authors also focus on neoliberalism (e.g., influences and networks) with attention on such broad areas as public education, Barack Obama's presidency, whiteness, racism, school networks, teacher professionalism, social movements, preservice teachers, decolonization, multicultural awareness, international field experience, and study abroad.

The authors use critical social and educational theories to explore and problematize, as well as interrogate, neoliberalism in its varied forms. We turn now to briefly describe each of the articles in this first issue of the two-volume set.

First, in "An Epistemic Frame Analysis of Neoliberal Culture and Politics in the US, UK, and the UAE: A Praxis for Regressionsverbot" authors Carol Mullen, Eugenie Samier, Sue Brindley, Fenwick English, and Nora Carr set in motion a thick description of the concept and practice of neoliberalism using an epistemic frame in which largely counterrevolutionary forces creatively destroy institutions and people's ways of life. They offer three case studies from different parts of the world that together provide a praxis for abolishing the backward movement of neoliberalism and the social losses it incurs.

Second, authors Dilys Schoorman and Michele Acker-Hocevar of the Florida Atlantic University and Washington State University, respectively, provocatively describe "Faculty Governance in Neoliberal Educational Contexts: Challenges for Democratic Decision Making." They adopt the position that faculty members are not immune from the deleterious impact of neoliberal values, policies, and practices that have turned universities into corporations and reduced teaching and research to products, faculty to "producers," and students to "clients." The authors argue that characteristics of desired communication practices for democratic decision making are needed for building a collective faculty capacity for responding to neoliberal agendas.

Next, from the University of the Pacific authors John Cassell and Thomas Nelson explore the neoliberal proposition that the "invisible hand" of the market is the most efficient and just mechanism for structuring economies, societies, and cultures. In "Exposing the Effects of the "Invisible Hand" of the Neoliberal Agenda on Institutionalized Education and the Process of Sociocultural Reproduction," they discuss modes of operation through which powerful networks of organizations dedicated to the prosecution of the neoliberal policy agenda run counter to the realities of overarching social structures in America.

Ending this collection, Christopher Tienken from Seton Hall University takes on education reform policies harvested from neoliberalism, social Darwinism, consumerism, and free-market ideologies in "Neoliberalism, Social Darwinism, and Consumerism Masquerading as School Reform." In this essay, he uses federal and state education reform policies and programs as examples of market-oriented ideologies embedded in the reforms. He argues that some federal education policies are illustrative of the confluence of ideologies that are creating a new meritocracybased system. He is concerned that the meritocracy-based system will disproportionately penalize poorer students and their preparation for formal schooling. 
Readers, the four articles featured in the second issue of this special issue are as follows:

1. Continuing Inequity through Neoliberalism: The Conveyance of White Dominance in the Educational Policy Speeches of President Barack Obama by Thomas W. Hairston

2. Turnaround as Reform: Opportunity for Meaningful Change or Neoliberal Posturing? by Ian M. Mette

3. Rethinking the Place of Networks in Education: Making the Case for Networks as Social Movements by Andrew Townsend

4. How Preservice Teachers Engage in the Process of (De)colonization: Findings From an International Field Experience in Honduras by Suniti Sharma, Jubin Rahatzad and JoAnn Phillion

With respect to acknowledgements, as guest editors we wish to express our appreciation to the contributors whom we are convinced have produced groundbreaking work that will hopefully serve to awaken institutions, policymakers, and the public. Moreover, we are grateful for the unwavering support and freedom we received from Editor Ian Winchester and editorial manager Denise Retzlaff and, formerly, Linda Lentz. Because of the latitude the Interchange editors gave us with this scholarly venture, we were all able to breathe into existence our ideas, concerns, and new possibilities. We would be remiss not to thank the reviewers who extended themselves all hours of the day and night on the global clock, providing detailed constructive critiques from which the articles most definitely benefitted. We are pleased to be contributing this special issue to a journal that has demonstrated its commitment to counter-hegemonic theories and arguments in the greater effort to imagine a better world and tomorrow.

As education scholar-practitioners, we seek to foster exchanges among practitioners, policymakers, and scholars and to provide a forum for comment on issues and trends in education. In the spirit of the journal, we have engaged in frank argumentative articles on the changing purposes of education. The articles challenge conventional assumptions about education and higher education and current trends in our institutional domains. We invite readers to respond, react, and shout out as they read our thoughts.

\section{References}

Bourdieu, P. (1998). Acts of resistance: Against the tyranny of the market (R. Nice, trans.). New York: New Press.

English, F. W. (2011). Educational leadership at century's beginning: A continuing search for the philosopher's stone. In F. W. English (Ed.), Introduction in the Sage handbook of educational leadership: Advances in theory, research, and practice (2nd ed., pp. vii-xiii). Thousand Oaks: Sage.

English, F. W., Papa, R., Mullen, C. A., \& Creighton, T. (2012). Educational leadership at 2050: Conjectures, challenges and promises. Lanham: Rowman and Littlefield Education.

Temes, P. S. (1996). Teaching leadership/teaching ethics: Martin Luther King's "Letter from Birmingham Jail". In P. Temes (Ed.), Teaching leadership: Essays in theory and practice (pp. 73-82). New York: Peter Lang. 